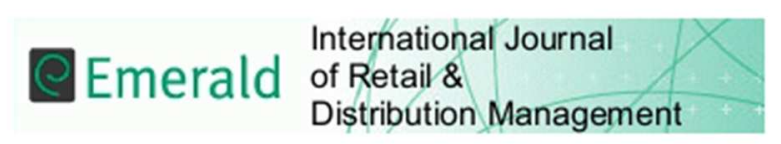

\title{
Engaging customers during a website visit: A model of website customer engagement
}

\begin{tabular}{|r|l|}
\hline Journal: & International Journal of Retail \& Distribution Management \\
\hline Manuscript ID & IJRDM-08-2015-0124.R4 \\
\hline Manuscript Type: & Research Paper \\
\hline Keywords: & $\begin{array}{l}\text { customer engagement, internet retailing, online consumer behaviour, } \\
\text { website attributes, environmental psychology, website design }\end{array}$ \\
\hline \multicolumn{2}{|l}{} \\
\hline
\end{tabular}

SCHOLARONE $^{\text {"x }}$

Manuscripts 


\title{
Engaging customers during a website visit:
}

\section{A model of website customer engagement}

\begin{abstract}
Purpose: A customer's visit to a retail website is a critical 'moment of truth' during which contemporary retailers attempt to simultaneously, during a single web navigation, capture customers' attention, build rapport and prompt them to act. By showing how to capture customer commitment over the course of a single website visit, the concept of customer website engagement, defined as 'the process of developing cognitive, affective and behavioural commitment to an active relationship with the website', addresses strategic concerns. Drawing from literature on engagement, this study considers how retail websites can engage customers during the course of a website navigation. A conceptual model of website customer engagement underpinned by relationship marketing and communication knowledge, shows how perceptions of the website's exploration and sense-making potential can activate consumer engagement, and is then empirically tested.

Design/methodology/approach: Using survey data, measures of the four dimensions of engagement (interaction engagement, activity engagement, behavioural engagement, and communication engagement) and of three drivers are developed and validated. The model is tested empirically $(\mathrm{n}=301)$ using structural equation modelling.

Findings: The results support the process conceptualisation of engagement, which identifies organismic as well as conative stages, and show the distinct roles played by perceptions of informational exploration, experiential exploration and sense-making in activating engagement.
\end{abstract}

Practical implications: The study provides online retailing practice with an organising framework enabling online retailing managers to consider how, depending on their product 
category and their size, they might (re)design their website to optimally produce customer engagement.

Originality/value: The study contributes to online marketing and retailing knowledge by showing the relevance of the concept of engagement as it pertains to customers' single navigations on retail websites, and by empirically showing, through a parsimonious model, how engagement can be activated and unfold.

Keywords: customer engagement; internet retailing; website attributes; online consumer behaviour; website design; environmental psychology

Paper type: Research paper 


\section{Engaging customers during a website visit:}

\section{A model of website customer engagement}

\section{Introduction}

A retail website constitutes an important touchpoint and a first online navigation can determine the future of a customer's relationship with retailers and their offerings. Retail websites host complex interactions, with online customers where communication and relational elements are inseparably interwoven, and the website's stimuli can simultaneously activate communication and relational responses. Such an interweaving of marketing communication and relational phenomena call for a considering of both domains, although marketing communication and relationship marketing have traditionally been separate managerial and scholarly concerns.

The concept of engagement, which describes a customer's experience of active connection or participation with a marketing entity (such as a brand, a firm, a website, an online community), could address the need to explain initial and on-going customer-website interactions comprehensively, by encompassing communication as well as relational properties. It has acquired much prominence in the practitioner literature (e.g. French et al., 2012; Gallup, 2014), reflecting marketers' compulsion to understand how, in today's overcrowded and fragmented marketing landscape, they might simultaneously capture customers' attention (Huddleston et al., 2015), build rapport with them and generate commitment to act. Scholarly attention has intensified recently (e.g. Brodie et al., 2013; Baldus et al., 2015; Bowden, 2009; Mollen and Wilson, 2010; Vivek, 2009; Brodie et al., 2011; Hollebeek et al., 2014).

Customer engagement can apply to a broad range of focal objects such as brands (Bowden, 2009; Sprott et al., 2009), organisations' innovation initiatives (Sawhney et al., 
2005), virtual communities (Brodie et al., 2013; Baldus et al., 2015). However, the question of why and how retail websites can engage customers on their first-time or subsequent visits remains open. Although a few studies have considered engagement in an online context (Mollen and Wilson, 2010; Hollebeek et al., 2014; Calder et al., 2009; Brodie et al., 2013; Pagani and Mirabello, 2011), none so far has considered the website itself as a focal object of engagement. A possible reason for this surprising situation is that the engagement process has mostly (although not always - see for instance Mollen and Wilson, 2010; Fredricks et al., 2004) been used to characterise a succession of interactions over time, rather than being considered in the context of a single interaction.

Yet, by showing how to capture customer commitment over the course of a single website visit, customer engagement addresses strategic concerns, since websites are often the first and only touchpoint through which retailers interact with their customers. Further, when the website is the locus of the first interaction with prospects or new customers, their engagement with the website may be a sine qua non condition for converting them into returning visitors or customers. Additionally, customer engagement can have consequences beneficial to the marketer beyond the customer's lifetime value, through referrals, influence and the contribution of feedback to the firm (Kumar et al., 2010). As the first step on the loyalty ladder, customer engagement may be key to profitability (Brodie et al., 2011).

Consequently, this study addresses the research question of how retail websites can engage customers during the course of a website navigation. Drawing from literature on engagement and environmental psychology, the paper develops a conceptualisation and model of website customer engagement underpinned by relational and communication knowledge, which it then tests. The study contributes to online marketing and retailing knowledge by showing the relevance of the concept of engagement as it pertains to customers' single individual navigations on retail websites, and by providing insights into 
how website perceptual attributes can activate website customer engagement. It provides online retailing practice with a framework enabling them to consider how, depending on their product category and their size, they might (re)design their website to optimally produce customer engagement.

\section{Theoretical background: Behaviour on the web and customer engagement}

The interactive and vivid qualities of the internet medium have been an early focus of the online marketing literature (e.g. Manganari et al., 2009). Several authors use different terminology to study the combination of cognitive and emotional phenomena that compel customers to attend to and interact with the stimuli of a website. One stream (e.g. Loiacono et al., 2007; Chang et al., 2014; Park et al., 2012) have drawn from offline atmospherics literature, to consider the 'silent language' (Kotler, 1973: , p. 48) of online communication, with a view to designing website stimuli which produce desirable customer responses. Another stream was initiated by Hoffman and Novak (1996), who extended the concept of flow (Csikszentmihalyi, 1990) to online contexts, suggesting that flow promotes 'stickiness' with the website and enhances customer experiences (Bilgihan et al., 2015; Rose et al., 2012; Shim et al., 2015).

Yet, the interactive nature of the internet also entails the development, during any online navigation session, of a relationship between the customer and the website (Dennis et al., 2009). Hence, the specific characteristics of internet behaviour such as interactivity (Steuer, 1992), customer participation (Meuter et al., 2003) and involving experiences (Hoffman and Novak, 1996) suggest the relevance of both relational and communications aspects. The concept of engagement, which describes a customer's active connection or commitment to a relationship with a marketing entity based on an experience or set of 
experiences, aptly captures the two aspects (relational and communicational) inherent in the interaction which customers develop with websites.

A review of extant typical conceptualisations of engagement (Table 1) reveals that while the concept has received much attention in the past decade from diverse disciplines, there remains much disparity about its domain and that some foci have received more attention than others.

INSERT TABLE 1 ABOUT HERE

Several general observations seem pertinent. First, with the exception of Webster and Ahuja (2006), these conceptualisations distinguish engagement from flow, involvement and interactivity because of the action orientation of engagement. Second, there is much divergence regarding the actual domain of engagement, some authors considering it as a behavioural construct, others seeing it as a strictly organismic construct, others as a process or a state within an ongoing process. Third, the process of engagement may be ongoing, i.e. applying to a succession of interactive experiences with the focal object, or it may apply to a particular experience or interaction. Fourth, there is also much diversity in terms of the focal object of engagement: a brand, a virtual community, offerings, websites, the organisation for which employees work, learning activities, or the product development and innovation activities of an organisation. Fifth, although the definitions in the marketing studies recognise the different, simultaneous roles that customers play as receivers and producers of communication, and as actors in a developing relationship with the focal object of engagement, the studies often only draw from either the marketing communication or the 
relationship marketing literature, rarely from both. Sixth, empirical studies and in particular measures of the concept remain scarce.

Several further matters arise with regard to studies that have considered the online context. So far, the literature has not examined engagement with a website other than from the perspective of the website representing the brand (Mollen and Wilson, 2010), the website being an advertising medium (Calder et al., 2009), or social television websites where the two-way interaction is with other viewers rather than the actual website (Pagani and Mirabello, 2011). Yet, in a retail context, websites are far more than advertising media or brand proxies: as environments, as service touchpoints, as the providers of multi-faceted information about offerings, they can make or break the 'moment of truth' which customers and prospects experience during the course of an online navigation. This moment of truth can have heavy consequences not only on purchases, but also in terms of the customer's disposition towards the retailer and their degree of 'active-ness' (positive or negative) towards the retailer and the website. Therefore, this paper argues that website customer engagement is a central construct to enable retailers to understand how, over the course a single navigation, they might grab customers' attention, develop a relationship with them and incite them to act within the context an increasingly interactive, fragmented and complex business environment.

Alongside Bowden (2009), this paper argues for a conceptualisation which acknowledges that engagement, rather than being only a psychological or a behavioural construct, is a process construct with both organismic and conative facets, to reflect the proactive notion underpinning the construct and distinguishing it from related constructs such as involvement. This approach is conducive to 'opening the black box' of customer engagement and understanding how it can be activated. Furthermore, alongside Calder, Malthouse, and Schaedel (2009), Mollen and Wilson (2010), and Webster and Ahuja (2006), this paper 
conceptualises the process of website customer engagement within the context of individual online navigation experiences.

Adapting Mollen and Wilson's (2010) definition to the focus of a marketing website, and reflecting the conceptualisation of engagement as a process taking place during individual navigations, website customer engagement is defined as the process of developing a cognitive, affective and behavioural commitment to an active relationship with the website.

This conceptualisation augments retailing and customer engagement literature since the particular focal object of engagement considered here (retail websites) has so far been neglected in the engagement literature. Due to the breadth of possible focal objects of engagement and the critical contextual influences on the processes underpinning customer engagement (Brodie et al., 2011), this conceptualisation is not simply an extension of extant theory to another context. Without conceptualisation work that takes account of the specific object of engagement, further conceptual development and empirical attempts at measuring and understanding the underlying elements of the engagement process would be hampered.

\section{Conceptual model}

Retail websites are virtual environments, and an online navigation exposes customers to their stimuli. As per Mehrabian and Russell's (1974) Stimulus - Organism - Response (SOR) model, stimuli generate a sequence of reactions: organismic reactions are internal states resulting from an immediate reaction to stimuli. In turn, they produce a behavioural response. We develop a conceptual framework using the SOR model and drawing from knowledge from relationship marketing and marketing communication literature to consider both relationship building and communication aspects underpinning the customer-website interaction on a retail website. 
In a first instance, we operationalise customer engagement as a set of organismic and conative responses to interactions with the attributes of a retail website and develop hypotheses linking the different components of customer engagement through a relational and a communication route. Second, we use environmental psychology literature to identify three relevant drivers of customer engagement and develop hypotheses regarding the manner they each activate a particular route of customer engagement.

\section{Operationalising website customer engagement}

The conceptualisation of website customer engagement has argued that customer engagement interweaves relationship marketing and marketing communication phenomena. We now deal with these in turn.

The Web facilitates relationship-building (Yoon et al., 2008). A relationship marketing perspective views customer navigations on a retail website as emergent relationships between the customer and the marketer, as the customer interacts with the website. Li, Browne and Wetherbe (2006) argue that there exists a relationship between websites and users that evolves over time, whose qualities in terms of trust and commitment, influences stickiness intention, or the "embedding [of] a website within a user's routine" (p. 106). This paper further posits that a single online navigation, in and of itself, also constitutes a marketing relationship: during the several minutes of the navigation, a relationship gradually develops, in which the customer discovers the manner in which the website works and responds to requests for further content, and establishes whether it is a suitable, useful and trustworthy website. Commitment at the end of a single navigation experience represents the customer's behavioural engagement with the site in future. Prior literature confirms links between intention and behaviour (e.g. Ajzen, 1991; Yun and Good, 2007), such that 
behavioural engagement would represent the conative element of the relational interaction between the website and the customer.

A determinant of commitment is the level of closeness and understanding experienced by the customer during the navigation. Interaction engagement refers to the degree of closeness that customers feel toward the website, depending on how well the site seems to understand them, adapt to them and meet expectations during the navigation session. Customers may experience interaction engagement when, during the navigation, the site behaves in a manner they understand and expect, both technically and by providing the content they anticipated from a hyperlink or a search. Feelings of identification and being understood are important because they imply that the marketer has something useful to offer the customer, or that the customer can psychologically identify with the marketer (Bhattacharya and Sen, 2003; Carlson et al., 2008). Service personnel who display interpersonal sensitivity and concern build rapport with consumers (Ashforth and Humphrey, 1993), which is likely to result in intentions to maintain that rapport. . Further, two-way communication has been shown to facilitate the development of relationships with online retail brands (Yoon et al., 2008) and argued to increase engagement (Brodie et al., 2011). Hence, when consumers perceive that a retail website is able to adapt to their questions, queries and requirements, according to engagement theory and relationship marketing principles, they will be more likely to return to that website.

The 'relational route' links interaction engagement and behavioural engagement. Behavioural engagement should derive from the immediate, organismic response of interaction engagement, such that customers who feel a stronger sense of identification and adaptation with a retail website should be more willing to return to the website.

\section{$H_{1}$ : Interaction engagement with a website positively influences behavioural} engagement engagement. 
Alongside the relationship building view discussed above, a marketing communication perspective views customer navigations on a retail website as conversations between a marketer and a customer, the two parties conceivably communicating while gradually building a relationship. Such a perspective would view each action by the customer (click on a hyperlink, type in a search and press enter) as a question, which is answered in the form of a new page. Thus, the interaction between the customer and the website takes the form of a dialogue, consisting of actions and page returns. The internet enables customers to control and choose the communication they receive from marketers (Hoffman and Novak, 1996; Ariely, 2000; Fortin and Dholakia, 2005). By virtue of this control and choice, customers become 'authors' of the content they receive (Shih, 1998). This authoring can be involving. Activity engagement refers to the level of involvement with the task of 'producing' communication by calling up different elements of content (clicking on hyperlinks, search for key terms, calling up product photographs etc.). Involved states have motivations properties (Mitchell, 1979; Rothschild, 1984); specifically, involved customers search for more information (Beatty and Smith, 1987), process information better (Chaiken, 1980) and are more involved with purchase decisions (Richard and Habibi, 2016). During a navigation, customers may become more active with the website, such as when they request more pages, explore the website more thoroughly, and pay more attention to information on the screen; or they may remain more passive and only look distractedly at a few pages, without focusing on anything or following through on any information.

Beyond the communication they expose themselves to during the course of the navigation, customers can also opt to remain in communication with the website in the future, by registering to receive alerts, future newsletters or by bookmarking the site they visit. Hence, communication engagement refers to the customer's commitment towards future dialogue with the website. Communication engagement is a form of commitment - which 
Moorman, Zaltman, and Deshpande (1992: , p. 316) define as "an enduring desire to maintain a valued relationship." With the internet technology though, communication engagement goes beyond desire, because customers can create a pull for future information in the here and now.

The 'communication route' links activity engagement and communication engagement. Hence, communication engagement is viewed as a conative response to the communication exchange between the customer and the website, which results from the immediate, organismic response of activity engagement. Specifically, more involved customers develop positive attitudes toward a site (Richard and Habibi, 2016), which prompts them to gather more information later (Richard and Chandra, 2005). To guarantee the flow of future information, customers request further communication in the present.

$H_{2}$ : Activity engagement with the website positively impacts communication engagement on the site.

Further, customers can form attachments to the object of involvement (Mittal, 1989; Broderick et al., 2007). Involvement has affective consequences (Mittal, 1989; Park and Moon, 2003), therefore customers experiencing a higher activity engagement are likely to develop stronger relational bonds with the website, as empirical studies show, which find relationships between website involvement and purchase intentions or approach attitudes (Kim et al., 2007; Richard and Habibi, 2016). Hence:

$H_{3}$ : Activity engagement with a website positively influences behavioural engagement with the site.

Additionally, the decision to request future communication from the website can be seen as evidence of the stickiness of the website, which can apply to both the duration and the frequency of a website's visit (Roy et al., 2014; Li et al., 2006), suggesting that customers wish to remain associated with the website and will use the further communication as an 
opportunity to revisit the site, for instance clicking on a hyperlink provided in an email or online newsletter. Further, as discussed earlier, communication engagement constitute a form of commitment to future interactions, and commitment has been identified in several studies as an antecedent to customer loyalty to commercial websites (see Toufaily et al., 2013; Wang et al., 2006). Hence:

\section{$\mathrm{H}_{4}$ : Communication engagement positively affects behavioural engagement with the} website.

\section{Drivers of website customer engagement}

According to the SOR model (Mehrabian and Russell, 1974), the organismic responses of customer engagement result from customers' perceptions of stimuli or attributes of the retail website during their navigation (Mollen and Wilson, 2010). Following the logic of Parasuraman et al's (2005) means-end framework, we chose to consider, as drivers of customer engagement, a website's perceptual attributes (i.e. the website characteristics comprising features, cues and functions, which are perceived by consumers as they use a retail website) rather than concrete cues (the individual elements which constitute a website), for two main reasons. First, cues may evolve with technology, whereas the perceptions of these cues in people's minds are more stable; second, people may not have the technical awareness or vocabulary to assess cues, whereas they are used to considering the more abstract level of perceptions.

To conceptualise how customers perceive retail websites, this study adopts the principles of Kaplan and Kaplan's (1982) Preference Framework, which stipulates that people's two main needs in an environment are to make sense and to explore. People use information from the environment to address these two needs. The two concepts of sensemaking and exploration are particularly apt in the context of online environments, as 
empirically verified by Rosen and Purinton (2004), Singh, Dalal, and Spears (2005),

Demangeot and Broderick (2010), and Brunner-Sperdin et al. (2014). Retail websites are less intuitive than offline shopping environments. They appear to the customer one page at a time, which complicates the task of making sense of the overall architecture and contents. For the same reasons, the hidden portions of the website (i.e., the parts that are not on the page on screen and are alluded to in the form of hyperlinks or clickable photographs, etc.) provide the potential for further exploration.

A website's potential for exploration can relate to both the experience of shopping, as in browsing or following links to more areas on the site, and the information that the site provides (Demangeot and Broderick, 2010). Thus, experiential exploration potential, or the website's ability to replicate the experience of abundance of a real retail environment, differs from informational exploration potential, or the provision and storage of vast amounts of searchable information (Burke, 2002) from both marketer and non-marketer sources. This distinction between two forms of exploration potential is important, because information, while not a predominant element of most landscapes and environments, is central to online marketing environments (Huang, 2000) and can add value to customers' online shopping experience (Koufaris, 2002). Regardless of whether they are browsing or engaging in goaldirected shopping, online customers are information seekers.

Customers who perceive a site as higher in experiential exploration potential likely visit more pages and become more interested and motivated (Kim et al., 2007), therefore a more active with the context (Ha and Lennon, 2010). Similarly, perceptions of high informational exploration potential should activate the same responses (Fortin and Dholakia, 2005). Hence:

$H_{5}:$ Perceptions of (a) experiential exploration potential and (b) informational exploration potential positively influence activity engagement with the website. 
Sense-making potential relates to the website's ability to facilitate the customer's orientation, navigation and task accomplishment. Customers who make sense of the website should feel more comfortable and understand the site, which in turn increases their sense of familiarity (Kaplan and Kaplan, 1982). Familiarity enables them to obtain more answers from the website, which can heighten their sense of closeness and identification. Moreover, during the navigation experience, customers who perceive the site as high in experiential exploration potential likely visit and explore more pages. Experiences produce strong emotional responses (Richins, 1997), so customers who engage in shopping experiences that are high in experiential exploration potential should develop stronger relational ties with the site.

$H_{6}:$ Perceptions of (a) sense-making potential and (b) experiential exploration potential positively impact interaction engagement.

Websites that offer informational exploration increase website familiarity (Richard and Habibi, 2016) and decrease levels of uncertainty towards decision-making (Mazaheri et al., 2011). Informativeness has also been found to be one of the contributors to website persuasiveness on travel websites (Kim and Fesenmaier, 2008). Hence, perceptions of informational exploration potential, by increasing familiarity with the site and decreasing uncertainty, should activate a stronger sense of feeling understood and adaptation of the website. Hence:

\section{$H_{6 c}$ : Perceptions of informational exploration potential positively influence} interaction engagement.

Consistent with the conceptualisation of separate routes (communication and relational) to engagement, it is hypothesised that specific drivers are more effective in activating one of the two routes. Interaction engagement with the site likely relies more on the provision of relevant information, which is known to enable customers to develop trust towards the marketer behind the site (Bauer et al., 2002). Concomitantly, activity engagement is likely 
more reliant on the experiential impact of the visual and immersive stimuli of the site (Fortin and Dholakia, 2005; Kim et al., 2007). Hence:

$H_{7}$ : Informational exploration potential activates interaction engagement with the site more than it does activity engagement.

$H_{8}$ : Experiential exploration potential activates activity engagement with the site navigation more than it does interaction engagement.

A visual representation of the conceptual model and the hypothesised relationships can be found (alongside hypothesis testing results discussed later) in Figure 1. Compared to other models of online shopping adoption (e.g. Dennis et al., 2009; Brunner-Sperdin et al., 2014; Wu et al., 2013; Richard and Habibi, 2016; Rose et al., 2012), the parsimonious model of customer engagement conceptualised here captures the dual challenge of relationship building and communication. It conceptualises the existence of two distinct routes (the relational route via interaction engagement and behavioural engagement, and the communication route via activity engagement and communication engagement) through which online retailers can use potent website attributes as levers to turn initial reactions into behavioural intentions.

\section{Method and procedure}

Because the purpose of the research is to consider how retail websites can engage customers during a single visit by developing and testing a model of website customer engagement, a survey research method was deemed to be the most appropriate. In particular, it was preferred to an experimental design, since the design of an experimental website the and manipulation of the drivers of website customer engagement (experiential exploration potential, informational exploration potential and sense-making potential) would have 
affected the realism of the participants' navigation, and therefore the study's external validity (Hair et al., 2006).

The target population for the study was defined as consumers who shop and purchase online regularly. A convenience sample of 301 volunteer U.K.-based students and university staff was recruited to test the nomological network. The sample was recruited via advertisements on campus, email, and via the network of student 'research assistants'. Participation was voluntary, but respondents were given the option of entering a raffle to win one of give items, the biggest prize being an iPod. In a university computer lab or at their workstations, the respondents navigated an online bookstore for eight minutes before they answered a questionnaire about their particular experience. The requirement that they navigate the website before answering the questionnaire added to the difficulty of collecting the data, but this procedure enabled a focus on respondents' perceptions of a specific, recent navigation rather than their memories or past perceptions of a random website. This step enhances the study's validity by avoiding halo or memory effects (Chen, Wigand, and Nilan, 1999).

The product category (books) of the stimulus is a common purchase among the respondents and increases the realism of the task. Within that product category, the study uses a relatively unknown site (only $7.3 \%$ of the sample reported that they had visited it before; none reported using it regularly) and therefore can capture fresh perceptions, untainted by the memory of previous visits or any loyalty to the site itself. The instructions asked the respondents to shop online as they would normally if they were at home, in an internet café, or at their desk. The instructions also contained examples of what respondents might want to do during the navigation session, such as "searching for a book [they] had in mind to purchase" or "browsing." 
The sample characteristics are described in Table 2. The recruitment of a convenience sample rather than the use of random sampling, due to the prohibitive costs of the latter, may affect the reliability of measures and the generalisability of the hypothesis testing results (Hair et al., 2006). Several elements mitigate these risks. First, in terms of the sample's relevance as reflective of the target population, $96.7 \%$ of the respondents had shopped online, and $94.7 \%$ had made purchases online; therefore the sample, while a convenience sample, undertook a realistic task. Additionally, while the sample, which consists of 214 university students and 87 university staff, remains a convenience sample, the nationality breakdown of the sample is reasonably reflective of the proportions of nationalities present on a UK university campus. The statistical checks carried out revealed that there were no significant differences between students and staff concerning the variables and relationships of interest, therefore both groups were combined. Half of the total sample (obtained by random split) provided input for the scale development, and the second half served scale validation purposes (Churchill, 1979). The testing of the nomological network employed the whole sample.

INSERT TABLE 2 ABOUT HERE

The procedure for developing reliable and valid measures of the seven constructs in the nomological framework followed accepted procedures (Churchill, 1979). The study operationalised activity engagement by adopting Mishra et al.'s (1993) involvement with the choice task measure. Convergent validity requirements (Hair et al., 2010) resulted in reducing the four-item measure to three items. 
Measures for the model's remaining six constructs were developed (or adapted) and validated. Although some of the constructs may describe phenomena that relate to wellknown constructs from relationship marketing, marketing communication, and environmental psychology literature, their application to the online context required sufficient changes, to warrant the rigorous development and validation process set out by Churchill (1979) and others (Anderson and Gerbing, 1988). These measures' items emanate from published scales (Agarwal and Karahanna, 2000; Aladwani and Palvia, 2002; Kim and Stoel, 2004; Liu, Arnett, Capella, and Taylor, 2001; Park and Kim, 2003; Venkatesh and Davis, 1996), an exploratory phase consisting of think-aloud protocols (Ericsson and Simon, 1993), and depth interviews with 19 informants.

Nine expert judges performed a sorting task of the 156 items gathered through these methods. According to the rules of interjudge reliability prevalent in marketing literature (e.g. Hardesty and Bearden, 2004), 106 items were appropriate for retention; a pilot test included these items in a questionnaire distributed to a convenience sample of 39 students. The final survey included 69 items selected on the basis of qualitative feedback, item-to-total correlations, and exploratory factor analysis. To guard against the possibility of response bias (Baumgartner and Steenkamp, 2001), each measure contained negatively worded items, and items from all seven measures appeared in a random sequence in the questionnaire.

To estimate the model, structural equation modelling was chosen in preference to other techniques such as ANOVA because this technique (1) simultaneously estimates several interrelated dependence relationships; (2) it enables the testing of indirect as well as direct relationships between constructs; and (3) can deal with relationships can include unobserved phenomena, for which measurement error is taken into account during the estimation (Hair et al., 1998). Furthermore, it is particularly well suited to permit the testing of several alternative models in order to assess their relative fit. In view of the small 
percentage of missing data (which ranged from 0 to $1.3 \%$ ) and its apparent randomness, imputation was preferred to any deletion method, in order to preserve the sample size and avoid estimation problems associated with the use of matrices of different sizes generated by pairwise deletions.

\section{Results}

Measure validation

Exploratory and confirmatory factor analyses helped purify and validate the measures. The Appendix provides the measures' psychometric properties. The measurement model displays acceptable goodness-of-fit: Chi-square $=893.87$, degrees of freedom $[\mathrm{df}]=474$ $(p=.000)$; root mean squared error of approximation $[$ RMSEA $]=.054$; confirmatory fit index $[\mathrm{CFI}]=.98 ; \mathrm{n}=301 ;$ square root mean residual $[\mathrm{SRMR}=.056]$. All seven measures have strong composite reliabilities, well above the recommended threshold of .60 (Bagozzi and Yi, 1988). Their average variances extracted are all above or within a few decimal points of the recommended .50 threshold (Bagozzi and Yi, 1988). The square of any correlation between two measures is less than the average variance extracted of each measure, in support of discriminant validity (Fornell and Larker, 1981). Additionally, for each for each pair of variables, the analysis tested nested two-factor models, where the correlation between the two factors was set free, then set to equality. All Chi-square differences are significant at the .005 level, implying all constructs have discriminant validity. Therefore, although the measures had originally been piloted on a test sample consisting only of students, they remained valid when administered to a wider group, thus adding weight to the argument that students constitute a suitable sample for this study. The latent variables' correlations and other statistics are shown in Table 3. 


\section{Hypothesis testing}

Structural equation modelling permits the test of hypothesised relationships between the constructs that constitute customer engagement and their drivers. The results suggest good model fit $($ Chi-square $=913.98$, degrees of freedom $[\mathrm{df}]=483$; root mean squared error of approximation $[\mathrm{RMSEA}]=.055$; confirmatory fit index $[\mathrm{CFI}]=.98$; square root mean residual $[\mathrm{SRMR}]=.059$; non-normed fit index $[\mathrm{NNFI}]=.98$ ); Figure 1 presents these results. The first set of hypotheses $\left(\mathrm{H}_{1}-\mathrm{H}_{4}\right)$ proposes a network of relationships between the four constructs of customer engagement. The results support these four hypotheses at the .001 level. The strongest relationship links activity engagement to communication engagement $(.66, \mathrm{t}=11.31)$. The relationships between communication engagement and behavioural engagement $(.38, \mathrm{t}=6.89)$, activity engagement and behavioural engagement $(.35, \mathrm{t}=4.84)$, and between interaction engagement and behavioural engagement $(.24, \mathrm{t}=4.16)$ are all significant.

\section{INSERT FIGURE 1 ABOUT HERE}

Regarding the relationships between customer engagement and its drivers, the structural equation model results support $\mathrm{H}_{5}-\mathrm{H}_{6}$ at the .05 level or higher. Informational exploration potential predicts both interaction engagement $(.64, \mathrm{t}=7.68)$ and activity engagement $(.39, \mathrm{t}=5.77)$; experiential exploration potential predicts both activity 
engagement $(.50, \mathrm{t}=6.41)$ and interaction engagement $(.19, \mathrm{t}=2.68)$. Sense-making potential is a weaker though still significant predictor of interaction engagement $(.15, \mathrm{t}=2.48)$.

To test the final hypotheses, $\mathrm{H} 7$ and $\mathrm{H} 8$, further analysis aimed to determine whether the drivers activate one route significantly more than the other. To investigate whether informational exploration potential activates the relational route more than the communication route, an alternative model was specified, in which the paths from informational exploration potential to interaction engagement and activity engagement were set equal, then free. The Chi-square difference between the two models, for one degree of freedom, is 4.38. Therefore, informational exploration potential activates the relational route significantly more than the communication route. In a similar investigation of whether experiential exploration potential activates the communication route more than the relational route, the Chi-square difference, for one degree of freedom, is 13.11. Hence, experiential exploration potential activates the communication route significantly more than the relational route.

The squared multiple correlations for each of the four structural equations indicate that the model explains $73 \%$ of the variability of interaction engagement, $63 \%$ of the variability of activity engagement, $44 \%$ of the variability of communication engagement, and $69 \%$ of the variability of behavioural engagement. The model therefore includes important predictors of customer engagement.

At best, a good fit between a model and the data indicates that the model provides a possible explanation of a phenomenon; therefore, an alternative model provides a means to assess relative fit. An alternative model was also tested, which features the four components of customer engagement as direct consequences of the three drivers, such that experiential exploration potential and informational exploration potential are antecedents of all four components, whereas sense-making potential is an antecedent only of interaction engagement 
and behavioural engagement. The antecedent-consequence relationships among the four components of customer engagement do not appear in the alternative model. Its goodness-offit indices reveal a far worse fit $($ Chi-square $=1045.34, \mathrm{df}=482 ; \mathrm{RMSEA}=.062 ; \mathrm{CFI}=.97$; $\mathrm{SRMR}=.065$ ). The comparison and resulting Chi-square difference of 131.36 (one degree of freedom) add further support to the two-step model of customer engagement developed here.

\section{Discussion}

\section{Theoretical implications}

Building on initial conceptualisations of customer engagement (Mollen and Wilson, 2010; Brodie et al., 2011; Vivek, 2009; Bowden, 2009; Hollebeek, 2011; van Doorn et al., 2010), this paper has proposed and tested a model of website customer engagement. Structural equation modelling results empirically support the two-step model that was developed and the hypothesised relationships between customer engagement and its three drivers. It also confirms the existence of two distinct routes to customer engagement, which can be activated separately by manipulating different website attributes.

This study offers four major implications. First, by distinguishing between organismic and conative responses, the model of customer engagement specifies, in interaction engagement and activity engagement, two distinct means of activation which prompt customers' desirable behaviours, namely, behavioural engagement and communication engagement. Both organismic responses predict behavioural engagement; activity engagement also affects communication engagement, which in turn influences behavioural engagement. Therefore, the model confirms the existence of both organismic and conative facets to engagement (Brodie et al., 2011) and clarifies the sequence of the responses to website attributes and pinpoints the importance for retailers of designing websites able to generate, concurrently, a close interaction with the site and an active experience. The 
predictive importance of activity engagement on both communication and behavioural engagement supports the proposition that participation in the production or delivery of a service (in this case, online retail shopping) is an antecedent of long-term customer engagement (Brodie et al., 2011).

Second, the findings support the existence of two distinct routes to customer engagement: experiential exploration potential activates activity engagement more than it develops interaction engagement, which suggests a marketing communication route; and informational exploration potential develops interaction engagement more than it creates activity engagement, which suggests a separate relationship marketing route. Different kinds of exploration potential therefore appear to activate different routes. While other models of online consumer behaviour (e.g. Richard and Habibi, 2016; Rose et al., 2012) have tended to privilege the communication and experiential side of consumer interactions with websites, our results show the similarly significant importance of the relationship route, which can be activated by the informativeness of the retail website. While website informativeness has been considered in earlier studies (e.g. Richard, 2005; Richard and Habibi, 2016; Mazaheri et al., 2011; Hausman and Siekpe, 2009), its influence on relationship building online has not been investigated.

Third, the study finds that activity engagement is more the result of experiential exploration potential than informational exploration potential, re-emphasising the importance of experiences in online shopping and service situations (Malthouse and Calder, 2011; Rose et al., 2012; Ding et al., 2010). Although customers may start a navigation with purely utilitarian intentions, their ultimate commitment to the site is enhanced by its experiential potential.

Fourth, a particularly interesting finding is that informational exploration potential activates the relational route of engagement more than its communication route. This 
suggests that in the absence of any human being during the navigation, the provision of abundant information can help develop a sense of closeness and understanding with the site. In the absence of service personnel, a B2C website's depth of information may enhance the relationship between the customer and the site, possibly by building trust through the provision of quality information (Li et al., 2006; Porter and Donthu, 2008). This result also echoes Sicilia and Ruiz's (2010) finding that even under high information load conditions, attitudes towards a website remain high, although a decline in cognitive processing happens beyond a certain level.

\section{Implications for practice}

When conceiving their website, retailers face the major challenge of designing an environment that can engage prospects and customers within the few minutes of a single navigation. This study provides an organising framework that enables retailers to deploy their online investments strategically towards this purpose.

The study identifies specific drivers that, by activating specific organismic responses, are able to commit customers to act. The two main activators of customer engagement, experiential exploration and informational exploration potential, work in a complementary manner. However, the study also provides more specific insights into which driver can be used to the most effect to develop relational or communication elements on online touchpoints.

To develop the relational route of customer engagement, retailers can focus on enhancing their website's potential for informational exploration. In particular, bearing in mind that the website may be the first and only touchpoint which customers or prospects access, retailers should ensure that the information they provide is sufficient to enable customers to complete their task. That task may simply be a general search, or the purchase 
of a needed item. For this purpose, adaptive websites that enable retailers to model customer online behaviour by comparing their first few steps on the website with generic models of behaviour, can more successfully pattern the subsequent pages they present to customers after their particular preferences, thus enhancing the likelihood of stronger interaction engagement, and stronger behavioural engagement. The strong relationship between informational exploration potential and interaction engagement also suggests that service providers and marketers of credence goods can go some way towards overcoming the challenges of humanless online operations, by developing their customers' interaction engagement through the abundant provision of information online. Taking account of the results presented here, together with those by Sicilia and Ruiz (2010) mentioned in the last section, retailers would be well advised to provide as much information on their website as they can, since this information serves, among other purposes, to build the relationship commitment of their customers.

To develop the communication route of customer engagement, marketers can focus on enhancing their website's potential for experiential exploration. The study results reinforce the importance of the experience of the navigation, which prompts activity engagement as well as, to a lesser degree, interaction engagement. Retailers, therefore, need to develop the experiential intensity of their website. Several individual elements can contribute to the development of a richer experience (Demangeot and Broderick, 2006), such as interactive images (Fiore et al., 2005), 3-d representations of products, or even environments in virtual worlds such as Second Life (Hoffman and Novak, 2009).

Finally, and importantly, rather than the judgment of expert website designers or marketers that might be measured through 'objective' scales, engagement is activated by customers' perceptions of website attributes. Accordingly, this study has developed valid measures that retailers can usefully administer to test-customers to evaluate the ability of 
their website to induce customer engagement, and to compare it with best-in-class or competitor websites. Retailers' main aim remains to ensure that the features and devices developed by the website designers work together, coherently, at enhancing customers' overall perceptions of experiential and informational exploration potential. In this sense, the constructs used here constitute a valuable 'vocabulary' for retailers to use when considering the performance or objectives of the website.

It is important to acknowledge that the potential for experiential exploration may be more costly to enhance than the potential for informational exploration since it typically involves much larger outlays to acquire advanced technology. Such investments are not at the disposal of all retailers. Smaller-scale retailers may therefore use the framework to realise that they may not be able to develop the communication route as powerfully as their larger competitors, in which case they should further emphasise the priority of making the most of the relational route, by maximising the website's informational exploration potential.

Finally, the results of our study can also be considered in the light of emerging business practice. In this respect, several observation appear pertinent. First, the importance of communication engagement and the communication route overall can be seen in the increasing number of alternative platforms (e.g. Facebook, Instagram, YouTube) on which retailers seek to gain their customers' communication engagement, hence also prompting further behavioural engagement. The different platforms, through their different functionalities, operate differently in potentially activating further activity engagement on the retail website. Second, the importance of informational exploration potential as a driver a customer engagement can be related to the increasing amount of content, whether retailer- or user-generated, displayed on retail websites. Third, the importance of the experiential exploration potential of a website can be related to the increasing use of technical means such as videos, auto-scrolling images, multiple views of a product, etc. used to enable consumers 
to have a vivid experience an online store and its products. Fourth, consistent with the findings of this study showing the weak role of sense-making potential in comparison to experiential exploration potential and informational exploration potential, practitioner conversation, which was initially focused on designing for functionality and ease of use, has now shifted towards the issues designing for experience and information, as attested by a number of 'how to' guides published in practitioner media (e.g. Schiff, 2015; McCreary, 2015). Fifth, let us also note that the elements of the experiential exploration potential and informational exploration potential of websites are now increasingly being used in brick and mortar environments such as Audi City, Primark, or New Balance (Charlton, 2013).

\section{Conclusion}

This study contributes to online marketing and retailing knowledge by empirically showing the relevance of the concept of engagement in the context of online retail environments and explaining how perceptions of website attributes activate engagement. In essence, this study 'opens the black box' of customer engagement in the context of retail websites, critical touchpoints accessed by customers and prospects alike. In a single, parsimonious model, the study has conceptualised and tested relationships between the four facets of engagement and, as antecedents, perceptions of informational exploration, experiential exploration, and sensemaking. In the process, it provides psychometrically valid measures of four dimensions of the engagement process and their drivers within an online retailing context.

Nevertheless, the study suffers from several limitations. The sample is a convenience sample; however due to their above-average internet literacy, the university students and staff who make up the sample are probably more representative of future customers, for whom marketers need to plan. In addition, this study focuses on a single product category, and the main survey related to a single website, although measure development utilised two different 
websites. Books tend to be involving; however, the relational route to engagement may be more prominent for product categories associated with higher levels of risk.

The study centres on the one-to-one interaction between online retailers and customers, without considering customers' ability to influence other customers through wordof-mouth or recommendations in social media. Further research should examine the strength of each route for activating customers' desire to produce recommendations or tell friends about the site. Does each route elicit a different kind of word-of-mouth activity? A crosssectional design limits the study's claim of causality. Further research could consider the relative effects of experiential and informational exploration potential by experimentally manipulating the attributes of a website.

Additional research, in particular interpretive research, should attempt to provide a deeper understanding of the process by which retails website attributes activate customer engagement. How does the potential for experiential exploration activate activity engagement, and what specific features are most successful in doing so? Similarly, how does the potential for informational exploration activate interaction engagement, and what particular features or interactions produce higher levels of such engagement?

As conceptualised and empirically validated in this article, the parsimonious nomological network of website customer engagement contributes to elucidating the dual marketing challenge of communication and relationship building. The identification of two distinct mechanisms through which website attributes activate engagement confirms the strategic importance of the phenomenon and endows it with sound theoretical foundations within a context of strategic importance to all retailers. 


\section{References}

Ajzen, I. (1991) "The theory of planned behavior", Organ, Behavior and Human Decision Processes, 50 (2), p 179-211.

Anderson, J.C. and Gerbing, D.W. (1988) "Structural equation modeling in practice: A review and recommended two-step approach", Psychological Bulletin, 103 (3), p 411423.

Ariely, D. (2000) "Controlling the information flow: Effects on consumers' decision making and preferences", Journal of Consumer Research, 27 (2), p 233-248.

Ashforth, B.E. and Humphrey, R.H. (1993) "Emotional labor in service roles: The influence of identity", Academy of Management Review, 18 (1), p 88-115.

Bagozzi, R.P. and Yi, Y. (1988) "On the evaluation of structural equation models", Journal of the Academy of Marketing Science, 16 (1), p 74-94.

Baldus, B.J., Voorhees, C. and Calantone, R. (2015) "Online brand community engagement: Scale development and validation", Journal of Business Research, 68 (5), p 978-985.

Bauer, H.H., Grether, M. and Leach, M. (2002) "Building customer relations over the Internet", Industrial Marketing Management, 31 (2), p 155-163.

Baumgartner, H. and Steenkamp, J.-B. (2001) "Response styles in marketing research: A cross-national investigation", Journal of Marketing Research, 38), p 143-156.

Beatty, S.E. and Smith, S.M. (1987) "External search effort: An investigation across several product categories", Journal of Consumer Research, 14), p 83-95.

Bhattacharya, C. and Sen, S. (2003) "Consumer-company identification: A framework for understanding consumers' relationships with companies", Journal of Marketing, 67 (April), p 86-88. 
Bilgihan, A., Nusair, K., Okumus, F. and Cobanoglu, C. (2015) "Applying flow theory to booking experiences: An integrated model in an online service context", Information \& Management, $52(6), \mathrm{p}$ 668-678.

Bowden, J.L.-H. (2009) "The process of customer engagement: A conceptual framework", Journal of Marketing Theory and Practice, 17 (1), p 63-74.

Broderick, A.J., Greenley, G.E. and Mueller, R.D. (2007) "The behaviourial homogeneity evaluation framework: Using consumer involvement in international segmentation", Journal of International Business Studies, 38 (5), p 99-108.

Brodie, R.J., Hollebeek, L., Juric, B. and Ilic, A. (2011) "Consumer engagement: Conceptual domain, fundamental propositions, and implications for research", Journal of Service Research, 14 (3), p 252-271.

Brodie, R.J., Ilic, A., Juric, B. and Hollebeek, L. (2013) "Consumer engagement in a virtual brand community: An exploratory analysis", Journal of Business Research, 66 (1), p 105-114.

Brunner-Sperdin, A., Scholl-Grissemann, U.S. and Stokburger-Sauer, N.E. (2014) "The relevance of holistic website perception. How sense-making and exploration cues guide consumers' emotions and behaviors", Journal of Business Research, 67 (12), p $2515-2522$.

Burke, R.R. (2002) "Technology and the customer interface: What consumers want in the physical and virtual store", Journal of the Academy of Marketing Science, 30 (4), p 411-432.

Calder, B.J., Malthouse, E.C. and Schaedel, U. (2009) "An experimental study of the relationship between online engagement and advertising effectiveness", Journal of Interactive Marketing, 23 (4), p 321-331. 
Carlson, B.D., Suter, T.A. and Brown, T.J. (2008) "Social versus psychological brand community: The role of psychological sense of brand community", Journal of Business Research, 61 (4), p 284-291.

Chaiken, S. (1980) "Heuristic versus systematic information processing and the use of source versus message cues in persuasion", Journal of Personality and Social Psychology, 39 (November), p 752-756.

Chang, S.-H., Chih, W.-H., Liou, D.-K. and Hwang, L.-R. (2014) "The influence of web aesthetics on customers' PAD", Computers in Human Behavior, 36), p 168-178.

Charlton, G. (2013) 11 great ways to use digital technology in retail stores. Econsultancy.

Churchill, G.A., Jr. (1979) "A paradigm for developing better measures of marketing constructs", Journal of Marketing Research, 16 (1), p 64-73.

Csikszentmihalyi, M. (1990) Flow: The psychology of optimal experience, HarperCollins, New York, NY.

Demangeot, C. and Broderick, A.J. (2006) "Exploring the experiential intensity of online shopping environments", Qualitative Market Research - An International Journal, 9 (4), p 325-351.

Demangeot, C. and Broderick, A.J. (2010) "Consumer perceptions of online shopping environments: A gestalt approach", Psychology \& Marketing, 27 (2), p 117-140.

Dennis, C., Merrilees, B., Jayawardhena, C. and Wright, L.T. (2009) "E-consumer behaviour", European Journal of Marketing, 43 (9), p 1121-1139.

Ding, D.X., Hu, P.J.-H., Verma, R. and Wardell, D.G. (2010) "The Impact of Service System Design and Flow Experience on Customer Satisfaction in Online Financial Services", Journal of Service Research, 13 (1), p 96-110. 
Fiore, A.M., Jin, H.-J. and Kim, J. (2005) "For fun and profit: Hedonic value from image interactivity and responses toward an online store", Psychology \& Marketing, 22 (8), p 669-694.

Fornell, C. and Larker, D.F. (1981) "Evaluating structural equation models with unobserved variables and measurement error", Journal of Marketing Research, 8 (1), p 39-50.

Fortin, D.R. and Dholakia, R.R. (2005) "Interactivity and vividness effects on social presence and involvement with a web-based advertisement", Journal of Business Research, 58 (3), p 387-396.

Fredricks, J.A., Blumenfeld, P.C. and Alison, H.P. (2004) "School engagement: Potential of the concept, state of the evidence", Review of Educational Research, 74 (1), p 59-109.

French, T., LaBerge, L. and Magill, P. (2012) Five 'no regrets' moves for superior customer engagement. McKinsey Quarterly. (accessed 15 February 2016).

Gallup. (2014) The State of the American Consumer: Insights for Business Leaders. 1-60.

Ha, Y. and Lennon, S.J. (2010) "Online visual merchandising (VMD) cues and consumer pleasure and arousal: Purchasing versus browsing situation", Psychology and Marketing, 27 (2), p 141-165.

Hair, J., Bush, R. and Ortinau, D. (2006) "Marketing Research within a changing environment. Revised international edition", McGraw-Hill, New York, USA, 589), p 566.

Hair, J.F., Anderson, R.E., Tatham, R.L. and Black, W.C. (1998) Multivariate data analysis, Prentice Hall International, Upper Saddle River, NJ.

Hair, J.F., Black, W.C., Babin, B.J. and Anderson, R.E. (2010) Multivariate Data Analysis, Prentice Hall, Upper Saddle River, NJ. 
Hardesty, D.M. and Bearden, W.O. (2004) "The use of expert judges in scale development: Implications for improving face validity of measures of unobservable constructs", Journal of Business Research, 57 (2), p 98-107.

Hausman, A.V. and Siekpe, J.S. (2009) "The effect of web interface features on consumer online purchase intentions", Journal of Business Research, 62 (1), p 5-13.

Hoffman, D.L. and Novak, T.P. (1996) "Marketing in hypermedia computer-mediated environments: Conceptual foundations", Journal of Marketing, 60 (3), p 50-68.

Hoffman, D.L. and Novak, T.P. (2009) "Flow online: Lessons learned and future prospects", Journal of Interactive Marketing, 23 (1), p 23-34.

Hollebeek, L. (2011) "Exploring customer brand engagement: Definition and themes", Journal of Strategic Marketing, 17 (7), p 555-573.

Hollebeek, L.D., Glynn, M.S. and Brodie, R.J. (2014) "Consumer Brand Engagement in Social Media: Conceptualization, Scale Development and Validation", Journal of Interactive Marketing, 28 (2), p 149-165.

Huang, M.H. (2000) "Information load: Its relationship to online exploratory and shopping behavior", International Journal of Information Management, 20 (5), p 337-347.

Huddleston, P., Behe, B.K., Minahan, S. and Fernandez, R.T. (2015) "Seeking attention: An eye tracking study of in-store merchandise displays", International Journal of Retail \& Distribution Management, 43 (6), p 561-574.

Kaplan, S. and Kaplan, R. (1982) Cognition and Environment, Praeger Publishers, New York, NY.

Kim, H. and Fesenmaier, D.R. (2008) "Persuasive design of destination web sites: An analysis of first impression", Journal of Travel Research). 
Kim, J., Fiore, A.M. and Lee, H.-H. (2007) "Influences of online store perception, shopping enjoyment, and shopping involvement on consumer patronage behavior towards an online retailer", Journal of Retailing and Consumer Services, 14 (2), p 95-107.

Kotler, P. (1973) "Atmospherics as a marketing tool", Journal of Retailing, 49 (4), p 48-64.

Koufaris, M. (2002) "Applying the technology acceptance model and flow theory to online consumer behavior", Information Systems Research, 13 (2), p 205-223.

Kumar, V., Aksoy, L., Donkers, B., Venkatesan, R., Wiesel, T. and Tillmanns, S. (2010) "Undervalued or overvalued customers: Capturing total customer engagement value", Journal of Service Research, 13 (3), p 297-310.

Li, D., Browne, G.J. and Wetherbe, J.C. (2006) "Why do Internet users stick with a specific website? A relationship perspective", International Journal of Electronic Commerce, $10(4)$, p 105-141.

Loiacono, E.T., Watson, R.T. and Goodhue, D.L. (2007) "WebQual: An instrument for consumer evaluation of Web sites", International Journal of Electronic Commerce, $11(3), \mathrm{p} 51-87$.

Malthouse, E.C. and Calder, B.J. (2011) "Engagement and experiences: Comment on Brodie, Hollenbeek, Juric and Ilic", Journal of Service Research, 14 (3), p 277-279.

Manganari, E.E., Siomkos, G., J. and Vrechopoulos, A., P. (2009) "Store atmosphere in web retailing", European Journal of Marketing, 43 (9), p 1140-1153.

Mazaheri, E., Richard, M.-O. and Laroche, M. (2011) "Online consumer behavior: Comparing Canadian and Chinese website visitors", Journal of Business Research, 64 (9), p 958-965.

McCreary, A. (2015) The Best And Worst Web Sites Of 2014: From Beautiful Design To Flawed Execution. Retail Touchpoints. (accessed 15 March 2016). 
Mehrabian, A. and Russell, J.A. (1974) An Approach to Environmental Psychology, The MIT Press, Cambridge, MA.

Meuter, M.L., Ostrom, A.L., Bitner, M.J. and Roundtree, R. (2003) "The influence of technology anxiety on consumer use and experiences with self-service technologies", Journal of Business Research, 56 (11), p 899-906.

Mishra, S., Umesh, U.N. and Stem, D.E.J. (1993) "Antecedents of the attraction effect: An information-processing approach", Journal of Marketing Research, 30 (3), p 331-349.

Mitchell, A.A. (1979) "Involvement: A potentially important mediator of consumer behaviour", in Wilkie, W.L. (Ed) Advances in Consumer Research. Association for Consumer Research, Ann Arbor, p 191-196.

Mittal, B. (1989) "Must consumer involvement always imply more information search?", in Srull, T.K. (Ed) Advances in Consumer Research. Association for Consumer Research, Provo, UT, p 167-172.

Mollen, A. and Wilson, H. (2010) "Engagement, telepresence and interactivity in online consumer experience: Reconciling scholastic and managerial perspectives", Journal of Business Research, 63 (9-10), p 919-925.

Moorman, C., Zaltman, G. and Deshpande, R. (1992) "Relationships between providers and users of marketing research: The dynamics of trust within and between organizations", Journal of Marketing Research, 29 (August), p 314-329.

Pagani, M. and Mirabello, A. (2011) "The influence of personal and social-interactive engagement in social TV Web sites ", International Journal of Electronic Commerce, $16(2), \mathrm{p} 41-67$.

Parasuraman, A., Zeithaml, V.A. and Malhotra, A. (2005) "E-S-QUAL: A Multiple-Item Scale for Assessing Electronic Service Quality", Journal of Service Research, 7 (3), p 213-233. 
Park, C.-W. and Moon, B.-J. (2003) "The relationship between product involvement and product knowledge: Moderating roles of product type and product knowledge type.", Psychology \& Marketing, 20 (11), p 977-997.

Park, E.J., Kim, E.Y., Funches, V.M. and Foxx, W. (2012) "Apparel product attributes, web browsing, and e-impulse buying on shopping websites", Journal of Business Research, 65 (11), p 1583-1589.

Porter, C.E. and Donthu, N. (2008) "Cultivating trust and harvesting value in virtual communities", Management Science, 54), p 113-128.

Richard, M.-O. (2005) "Modeling the impact of internet atmospherics on surfer behavior", Journal of Business Research, 58 (12), p 1632-1642.

Richard, M.-O. and Chandra, R. (2005) "A model of consumer web navigational behavior: Conceptual development and implications", Journal of Business Research, 58 (8), p 1019-1029.

Richard, M.-O. and Habibi, M.R. (2016) "Advanced modeling of online consumer behavior: The moderating roles of hedonism and culture", Journal of Business Research, 69 (3), p 1103-1119.

Richins, M.L. (1997) "Measuring emotions in the consumption experience", Journal of Consumer Research, 24 (2), p 127-146.

Rose, S., Clark, M., Samouel, P. and Hair, N. (2012) "Online customer experience in eretailing: an empirical model of antecedents and outcomes", Journal of Retailing, 88 (2), p 308-322.

Rosen, D.E. and Purinton, E. (2004) "Website design: Viewing the web as a cognitive landscape", Journal of Business Research, 57 (7), p 787-794.

Rothschild, M.L. (1984) "Perspectives on involvement: Current problems and future directions.", Advances in Consumer Research, 11), p 216-217. 
Roy, S.K., Lassar, W.M. and Butaney, G.T. (2014) "The mediating impact of stickiness and loyalty on word-of-mouth promotion of retail websites: A consumer perspective", European Journal of Marketing, 48 (9/10), p 1828-1849.

Sawhney, M., Veronba, G. and Prandelli, E. (2005) "Collaborating to create: The internet as a platform for customer engagement in product innovation", Journal of Interactive Marketing, 19 (4), p 4-17.

Schiff, J.L. (2015) 12 ways to improve the customer experience for online shoppers. CIO. (accessed 15 March 2016 ).

Shih, C.-F.E. (1998) "Conceptualizing consumer experiences in cyberspace", European Journal of Marketing, 32 (7/8), p 655-663.

Shim, S.I., Forsythe, S. and Kwon, W.-S. (2015) "Impact of Online Flow On Brand Experience and Loyalty", Journal of Electronic Commerce Research, 16 (1), p 56.

Sicilia, M. and Ruiz, S. (2010) "The effect of web-based information availability on consumers' processing and attitudes", Journal of Interactive Marketing, 24 (1), p 3141.

Singh, S.N., Dalal, N. and Spears, N. (2005) "Understanding web home page perception", European Journal of Information Systems, 14), p 288-302.

Sprott, D., Czellar, S. and Spangenberg, E. (2009) "The importance of a general measure of brand engagement on market behavior: Development and validation of a scale", Journal of Marketing Research, 46 (February), p 92-104.

Steuer, J. (1992) "Defining virtual reality: Dimensions determining telepresence", Journal of Communication, 42 (4), p 73-93.

Toufaily, E., Ricard, L. and Perrien, J. (2013) "Customer loyalty to a commercial website: Descriptive meta-analysis of the empirical literature and proposal of an integrative model", Journal of Business Research, 66 (9), p 1436-1447. 
van Doorn, J., Lemon, K.N., Mittal, V., Nass, S., Pick, D., Pirner, P. and Verhoef, P.C. (2010) "Customer Engagement Behavior: Theoretical Foundations and Research Directions", Journal of Service Research, 13 (3), p 253-266.

Vivek, S. (2009) A scale of consumer engagement. Department of Management and Marketing. Tucsaloosa: University of Alabama, 233.

Wang, H.-C., Pallister, J.G. and Foxall, G.R. (2006) "Innovativeness and Involvement as Determinants of Website Loyalty: I. A test of the style/involvement model in the context of Internet buying", Technovation, 26 (12), p 1357-1365.

Webster, J. and Ahuja, J.S. (2006) "Enhancing the design of web navigation systems: The influence of user disorientation on engagement and performance", MIS Quarterly, 30 (3), p 661-678.

Wu, W.-Y., Lee, C.-L., Fu, C.-S. and Wang, H.-C. (2013) "How can online store layout design and atmosphere influence consumer shopping intention on a website?", International Journal of Retail \& Distribution Management, 42 (1), p 4-24.

Yoon, D., Choi, S.M. and Sohn, D. (2008) "Building customer relationships in an electronic age: The role of interactivity of E-commerce Web sites", Psychology and Marketing, $25(7)$, p 602-618.

Yun, Z.S. and Good, L.K. (2007) "Developing customer loyalty from e-tail store image attributes", Managing Service Quality: An International Journal, 17 (1), p 4-22. 
Figure 1: Nomological net of website customer engagement and hypothesis testing results

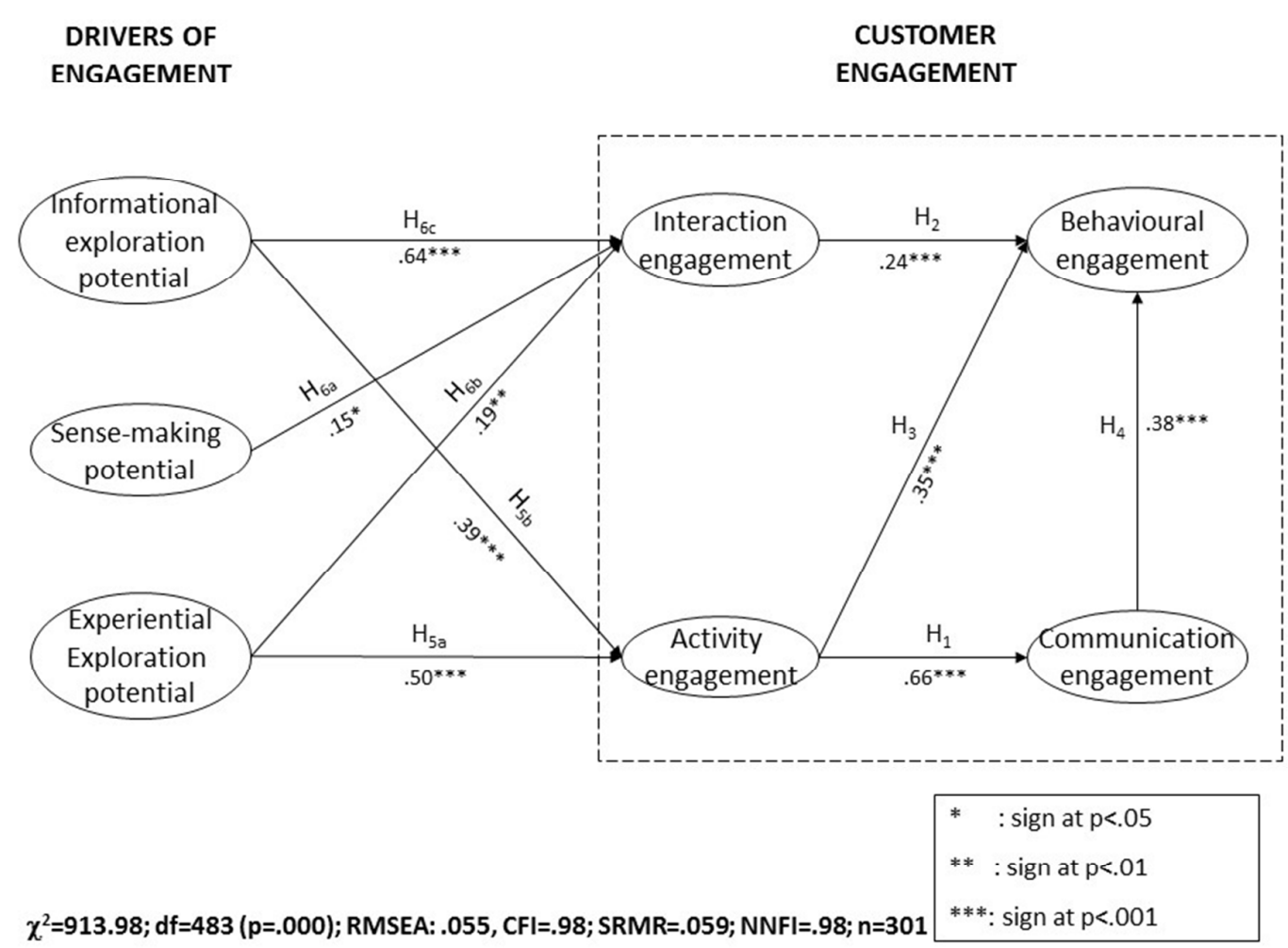


Table 1: Main Extant Conceptualisations of Engagement

\begin{tabular}{|c|c|c|c|c|c|}
\hline Author(s) & $\begin{array}{l}\text { Focus of } \\
\text { engagement }\end{array}$ & Definitional notions & Domain & $\begin{array}{l}\text { Literature base of } \\
\text { conceptualisation }\end{array}$ & $\begin{array}{l}\text { Measurement } \\
\text { developed? }\end{array}$ \\
\hline Baldus et al. (2015) & $\begin{array}{l}\text { Online brand } \\
\text { community }\end{array}$ & $\begin{array}{l}\text { 'the compelling, intrinsic motivations to continue } \\
\text { interacting with an online brand community' }\end{array}$ & Motivational state & $\begin{array}{l}\text { Consumer } \\
\text { motivations }\end{array}$ & $\begin{array}{l}11 \text { dimensions of } \\
\text { motivations to } \\
\text { engage }\end{array}$ \\
\hline Bowden (2009) & Brand & $\begin{array}{l}\text { 'a psychological process that models the underlying } \\
\text { mechanisms by which customer loyalty forms for new } \\
\text { customers of a service brand as well as the mechanisms } \\
\text { by which loyalty may be maintained for repeat purchase } \\
\text { customers of a service brand.' }\end{array}$ & Ongoing process & $\begin{array}{l}\text { Relationship } \\
\text { marketing }\end{array}$ & No \\
\hline $\begin{array}{l}\text { Brodie, Hollebeek, Juric } \\
\text { and Ilic (2011) }\end{array}$ & All foci & $\begin{array}{l}\text { 'a psychological state that occurs by virtue of interactive, } \\
\text { cocreative experiences with a focal agent/object (e.g. a } \\
\text { brand) in focal service relationships. [...] It is a multi- } \\
\text { dimensional concept subject to a context-specific and/or } \\
\text { stakeholder-specific expression of relevant cognitive, } \\
\text { emotional and/or behavioural dimensions.' }\end{array}$ & $\begin{array}{l}\text { State within an } \\
\text { ongoing process }\end{array}$ & $\begin{array}{l}\text { Relationship } \\
\text { marketing }\end{array}$ & No \\
\hline Brodie et al. (2013) & $\begin{array}{l}\text { Virtual } \\
\text { community }\end{array}$ & $\begin{array}{l}\text { 'a context-dependent, psychological state characterised } \\
\text { by fluctuating intensity levels that occur within dynamic, } \\
\text { iterative engagement processes' }\end{array}$ & $\begin{array}{l}\text { State within an } \\
\text { ongoing process }\end{array}$ & $\begin{array}{l}\text { Relationship } \\
\text { marketing }\end{array}$ & No \\
\hline
\end{tabular}




\begin{tabular}{|c|c|c|c|c|c|}
\hline Author(s) & $\begin{array}{l}\text { Focus of } \\
\text { engagement }\end{array}$ & Definitional notions & Domain & $\begin{array}{l}\text { Literature base of } \\
\text { conceptualisation }\end{array}$ & $\begin{array}{l}\text { Measurement } \\
\text { developed? }\end{array}$ \\
\hline Calder et al. (2009) & $\begin{array}{l}\text { Web site as } \\
\text { advertising } \\
\text { medium }\end{array}$ & $\begin{array}{l}\text { manifested in specific experiences with the Web site, } \\
\text { and which causes one to feel connected towards the } \\
\text { focus of engagement }\end{array}$ & $\begin{array}{l}\text { Organismic, } \\
\text { relates to specific } \\
\text { experience }\end{array}$ & $\begin{array}{l}\text { Marketing } \\
\text { communication }\end{array}$ & $\begin{array}{l}\text { Personal } \\
\text { engagement, } \\
\text { social-interactive } \\
\text { engagement }\end{array}$ \\
\hline Hollebeek et al. (2014) & Brand & $\begin{array}{l}\text { 'a consumer's positively valenced cognitive, emotional } \\
\text { and behavioural brand-related activity during, or related } \\
\text { to, specific consumer/brand interactions'. }\end{array}$ & $\begin{array}{l}\text { State within an } \\
\text { ongoing process }\end{array}$ & $\begin{array}{l}\text { Relationship } \\
\text { marketing }\end{array}$ & $\begin{array}{l}\text { Cognitive } \\
\text { processing, } \\
\text { affection, } \\
\text { activation }\end{array}$ \\
\hline Kahn (1990) & $\begin{array}{l}\text { Employees' } \\
\text { organisation }\end{array}$ & $\begin{array}{l}\text { 'the simultaneous employment and expression of a } \\
\text { person's 'preferred self' in task behaviours that promote } \\
\text { connections to work and to others, personal presence } \\
\text { (physical, cognitive, and emotional), and active, full role } \\
\text { performances'. }\end{array}$ & $\begin{array}{l}\text { State within an } \\
\text { ongoing process }\end{array}$ & Job design & No \\
\hline $\begin{array}{l}\text { Kearsley and } \\
\text { Shneiderman (1998) }\end{array}$ & $\begin{array}{l}\text { Learning } \\
\text { activities }\end{array}$ & $\begin{array}{l}\text { 'all student activities involve active cognitive processes } \\
\text { such as creating, problem-solving, reasoning, decision- } \\
\text { making, and evaluation. In addition, students are } \\
\text { intrinsically motivated to learn due to the meaningful } \\
\text { nature of the learning environment and activities' }\end{array}$ & $\begin{array}{l}\text { Organismic and } \\
\text { behavioural }\end{array}$ & Education & No \\
\hline
\end{tabular}




\begin{tabular}{|c|c|c|c|c|c|}
\hline (3) & $\begin{array}{l}\text { Focus of } \\
\text { engagement }\end{array}$ & Definitional notions & Domain & $\begin{array}{l}\text { Literature base of } \\
\text { conceptualisation }\end{array}$ & $\begin{array}{l}\text { Measurement } \\
\text { developed? }\end{array}$ \\
\hline Mollen and Wilson (2010) & $\begin{array}{l}\text { Web site as } \\
\text { personalising } \\
\text { a brand }\end{array}$ & $\begin{array}{l}\text { 'a cognitive and affective commitment to an active } \\
\text { relationship with the brand' }\end{array}$ & $\begin{array}{l}\text { State (emotional } \\
\text { and cognitive) } \\
\text { within one } \\
\text { interaction }\end{array}$ & Communication & No \\
\hline $\begin{array}{l}\text { Pagani and Mirabello } \\
\text { (2011) }\end{array}$ & $\begin{array}{l}\text { Social } \\
\text { television } \\
\text { Web site }\end{array}$ & $\begin{array}{l}\text { 'a collection of qualitative experiences with the } \\
\text { medium'. }\end{array}$ & $\begin{array}{l}\text { Organismic } \\
\text { within an ongoing } \\
\text { Web site } \\
\text { relationship }\end{array}$ & $\begin{array}{l}\text { Marketing } \\
\text { communication }\end{array}$ & $\begin{array}{l}\text { Personal } \\
\text { engagement; } \\
\text { social-interactive } \\
\text { engagement }\end{array}$ \\
\hline $\begin{array}{l}\text { Sawhney, Veronba and } \\
\text { Prandelli (2005) }\end{array}$ & $\begin{array}{l}\text { Product } \\
\text { development } \\
\text { and } \\
\text { innovation }\end{array}$ & 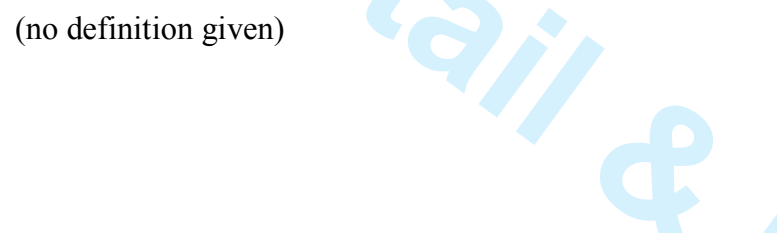 & Behavioural & $\begin{array}{l}\text { Marketing } \\
\text { communication }\end{array}$ & No \\
\hline $\begin{array}{l}\text { Sprott, Czellar and } \\
\text { Spangenberg (2009) }\end{array}$ & Brand & $\begin{array}{l}\text { 'an individual difference representing consumers' } \\
\text { propensity to include important brands as part of how } \\
\text { they view themselves.' }\end{array}$ & Individual trait & Branding & $\begin{array}{l}\text { Brand } \\
\text { engagement in } \\
\text { self-concept }\end{array}$ \\
\hline Van Doorn et al. (2010) & Brand & $\begin{array}{l}\text { 'Customers' behavioural manifestation toward a brand or } \\
\text { firm, beyond purchase, resulting from motivational } \\
\text { drivers such as word-of-mouth activity, } \\
\text { recommendations, helping other customers, blogging, } \\
\text { writing reviews.' }\end{array}$ & Behavioural & Branding & No \\
\hline Author(s) & Focus of & Definitional notions & Domain & Literature base of & Measurement \\
\hline
\end{tabular}




\begin{tabular}{|c|c|c|c|c|c|}
\hline & engagement & & & conceptualisation & developed? \\
\hline Vivek (2009) & $\begin{array}{l}\text { Offerings, } \\
\text { brands, firms, } \\
\text { activities }\end{array}$ & $\begin{array}{l}\text { 'the intensity of consumers' participation and connection } \\
\text { with [the focus of engagement]' }\end{array}$ & Behavioural & $\begin{array}{l}\text { Relationship } \\
\text { marketing }\end{array}$ & $\begin{array}{l}\text { Customer } \\
\text { engagement }\end{array}$ \\
\hline Webster and Ahuja (2006) & Web site & More passive state than flow and involvement & $\begin{array}{l}\text { Cognitive state } \\
\text { within one } \\
\text { interaction }\end{array}$ & Information systems & $\begin{array}{l}\text { Engagement with } \\
\text { the information } \\
\text { system }\end{array}$ \\
\hline This study & Website & $\begin{array}{l}\text { 'the process of developing a cognitive, affective and } \\
\text { behavioural commitment to an active relationship with } \\
\text { the website' }\end{array}$ & Ongoing process & $\begin{array}{l}\text { Marketing } \\
\text { communication and } \\
\text { relationship } \\
\text { marketing }\end{array}$ & $\begin{array}{l}\text { Interaction } \\
\text { engagement, } \\
\text { activity } \\
\text { engagement, } \\
\text { behavioural } \\
\text { engagement, } \\
\text { communication } \\
\text { engagement }\end{array}$ \\
\hline
\end{tabular}


Table 2: Sample Characteristics

\begin{tabular}{lr}
\hline Sample characteristics & \\
\hline Sample size & 301 \\
University students & 214 \\
University staff & 87 \\
\hline Sample's nationalities & \\
British & $71.4 \%$ \\
Asian & $15.9 \%$ \\
Other European & $8.6 \%$ \\
American & $2.0 \%$ \\
Middle Eastern & $1.0 \%$ \\
African & $.7 \%$ \\
Unknown & $.3 \%$ \\
\hline Percentage of sample that has shopped online & $96.7 \%$ \\
\hline Percentage of sample that has made purchases & $94.7 \%$ \\
online & \\
\hline
\end{tabular}


Table 3: Means, Standard Deviations and Correlations of Variables

\begin{tabular}{|c|c|c|c|c|c|c|c|}
\hline Variables & M & SD & 1 & 2 & 3 & 4 & 5 \\
\hline 1 Behavioural engagement & 2.51 & 1.10 & & & & & \\
\hline 2 Communication engagement & 2.09 & .97 & .70 & & & & \\
\hline 3 Activity engagement & 2.80 & .89 & .58 & .68 & & & \\
\hline 4 Interaction engagement & 3.11 & .84 & .59 & .31 & .46 & & \\
\hline 5 Experiential exploration potential & 2.60 & .90 & .55 & .54 & .67 & .58 & \\
\hline 6 Informational exploration potential & 3.28 & .80 & .56 & .36 & .54 & .66 & .65 \\
\hline 7 Sense-making potential & 3.88 & .83 & .35 & .20 & .29 & .57 & .37 \\
\hline \multicolumn{8}{|c|}{ Notes: all correlations significant at $p<0.05$ (two-tailed) level. } \\
\hline
\end{tabular}




\section{Appendix: Measures developed and validated for this study}

\begin{tabular}{|c|c|c|c|}
\hline Construct/Item Wording & $\begin{array}{l}\text { Composite } \\
\text { Reliability }\end{array}$ & $\begin{array}{r}\text { Average } \\
\text { Variance } \\
\text { Extracted }\end{array}$ & $\begin{array}{r}\text { Completely } \\
\text { Standardized Loading } \\
(\mathrm{t}-\text { Value })\end{array}$ \\
\hline Activity engagement & .85 & .65 & \\
\hline The navigation was stimulating & & & $.79(\mathrm{t}=14.66)$ \\
\hline The navigation was enjoyable & & & $.81(\mathrm{t}=15.19)$ \\
\hline The navigation was exciting & & & $.82(*)$ \\
\hline Interaction engagement & .81 & .51 & \\
\hline \multicolumn{3}{|c|}{ Interacting with the website gave me answers to my questions } & $.71(\mathrm{t}=12.38)$ \\
\hline \multicolumn{3}{|c|}{ I felt as if I was actually getting answers to what I was after on this website } & $.65(\mathrm{t}=11.08)$ \\
\hline \multicolumn{3}{|c|}{ This website didn't understand what I'm interested in (R) } & $.71(\mathrm{t}=12.40)$ \\
\hline \multicolumn{3}{|l|}{ This website didn't understand my needs (R) } & $.79(*)$ \\
\hline Communication engagement & .90 & .70 & \\
\hline
\end{tabular}

If the website had a function enabling me to register for email alerts, I would register.

$.87(\mathrm{t}=23.90)$

I would refuse to let this website contact me for special offers or promotions (R)

$.57(\mathrm{t}=11.23)$

I would like this website to keep in touch with me through email.

$.90(\mathrm{t}=26.61)$

I would register to receive newsletters from this website

$$
.94(*)
$$

\section{Behavioural engagement}

.94

.80

I will visit this site first when I want to buy books

$.78(\mathrm{t}=18.72)$

I plan to use this website in the future

$.90(\mathrm{t}=26.38)$

I intend to continue using this website in the future

$.95(\mathrm{t}=30.30)$

I expect my use of this website to continue in the future

$.92(*)$ 
This website was incapable of reproducing the excitement of shopping (R)

This website replicated the kind of experience I have when I shop

$.67(\mathrm{t}=9.26)$

When I navigated this website I felt I was shopping for real

$.70(\mathrm{t}=9.51)$

The experience of shopping was not there when I navigated on this site (R)

$.73(\mathrm{t}=9.78)$

Informational exploration potential

.84

I could learn a lot about the products

$.71(\mathrm{t}=12.46)$

This website provided complete product description

$.60(\mathrm{t}=10.21)$

This website adequately met my information needs

This site had insufficient product information $(\mathrm{R})$

$.71(\mathrm{t}=12.32)$

There wasn't enough information on this website to make a purchase decision (R)

$.60(\mathrm{t}=10.27)$

There was enough information on this website to assess the products

$.65(\mathrm{t}=11.14)$

\section{Sense-making potential}

The content on the website was clear

The information on this website was disorganized (R)

The organization of the information presented on the screen was confusing $(R)$

The content on this site was well organized

My interaction with this website is clear and understandable

The web pages were easy to read

The links and buttons on this website made sense

The categories and buttons were difficult to understand (R)

$\chi^{2}=893.87, d f=474(\mathrm{p}=.000) ; R M S E A=.054 ; C F I=.98 ; n=301 ; S R M R=.056$

*The metric for each scale was established by fixing one of the construct indicators to 1.00.

(R): Item was reverse-scored.
.88

.47

$.80(\mathrm{t}=11.79)$

$.65(\mathrm{t}=9.93)$

$.66(*)$

$.67(\mathrm{t}=10.27)$

$.75(\mathrm{t}=11.22)$

$.70(\mathrm{t}=10.55)$

$.64(\mathrm{t}=9.78)$

$.63(\mathrm{t}=9.73)$ 